\title{
Insight into the Composition of the Stabilized Residual from a Full-Scale Mechanical-Biological Treatment (MBT) Plant in Terms of the Potential Recycling and Recovery of Its Contaminants
}

\author{
Katarzyna Bernat *(D), Irena Wojnowska-Baryła, Magdalena Zaborowska (D) and Izabela Samul \\ Department of Environmental Biotechnology, University of Warmia and Mazury in Olsztyn, Sloneczna 45G, \\ 10-709 Olsztyn, Poland; irka@uwm.edu.pl (I.W.-B.); magdalena.zaborowska@uwm.edu.pl (M.Z.); \\ izabela.samul@uwm.edu.pl (I.S.) \\ * Correspondence: bernat@uwm.edu.pl
}

Citation: Bernat, K.;

Wojnowska-Baryła, I.; Zaborowska, M.; Samul, I. Insight into the Composition of the Stabilized Residual from a Full-Scale

Mechanical-Biological Treatment (MBT) Plant in Terms of the Potential Recycling and Recovery of Its Contaminants. Sustainability 2021, 13, 5432. https://doi.org/10.3390/ su13105432

Academic Editor: Barry D. Solomon

Received: 14 April 2021

Accepted: 5 May 2021

Published: 12 May 2021

Publisher's Note: MDPI stays neutral with regard to jurisdictional claims in published maps and institutional affiliations.

Copyright: (C) 2021 by the authors. Licensee MDPI, Basel, Switzerland. This article is an open access article distributed under the terms and conditions of the Creative Commons Attribution (CC BY) license (https:/ / creativecommons.org/licenses/by/ $4.0 /)$.

\begin{abstract}
There is a lack of knowledge about the composition and particle size distribution of the $<80 \mathrm{~mm}$ fraction mechanically separated from residual municipal solid waste (rMSW) and the stabilized residual (SR) after aerobic stabilization in a full-scale MBT plant. Therefore, the composition of the particle size fractions ( $>60 \mathrm{~mm}, 60-40 \mathrm{~mm}, 40-10 \mathrm{~mm}$ ) of the $<80 \mathrm{~mm}$ fraction and SR, collected in all seasons (summer (S), autumn (A), winter (W), spring (Sp)), was determined. Biodegradable waste (vegetable waste, other organic waste, paper, cardboard) constituted from $44.1 \%$ (A) to $54.3 \%$ (Sp) of the $<80 \mathrm{~mm}$ fraction and it decreased to $8.5 \%(\mathrm{~W})$ to $17.1 \%(\mathrm{~S})$ in the SR, after effective biodegradation. In SR, the smaller particle size fractions (up to $40 \mathrm{~mm}$ ) predominated. The main contaminants in SR were plastic, glass, metal, and other waste. Hierarchical clustering indicated that the composition of the particle size fractions of SR was more similar across four seasons than that of the $<80 \mathrm{~mm}$ fraction. After stabilization and separation, the share of contaminants increased in the SR size fractions, which means that their recovery before landfilling may be profitable. This suggests a new direction in waste management that would be consistent with the principles of a circular economy, in which a waste product, like SR, which previously could only be landfilled, becomes a source of secondary materials.
\end{abstract}

Keywords: stabilized residual; biodegradable waste; contamination ratio; similarity of particle size fractions; glass recovery

\section{Introduction}

Landfilling remains the most common method of disposing of residual municipal solid waste (rMSW). Generally, the rMSW relates to waste left mainly from households containing materials that have not been separated out during selective collection. To reduce the environmental impact of landfilling, rMSW has to be prepared for disposal in mechanicalbiological treatment (MBT) plants.

In MBT facilities in Poland, two types of waste are received and treated independently. First, plastic, metal, paper and glass that were separately collected are manually and automatically divided into several fractions based on the type of recyclable material. Second, rMSW is screened commonly in trommel rotary sieves. The fine fraction from these sieve consists of mostly organic matter and is sent to either anaerobic digestion or aerobic stabilization. Moreover, separately collected biowaste may be also treated in these two processes. The coarse fraction is a source of recyclable materials, which are recovered from it. The remaining fraction is called refuse-derived fuel (RDF), which is about $40 \%$ by weight of the input rMSW [1].

Biological stabilization is intended to reduce the weight of the organic fraction, and to render inert any biologically active organic materials, thus producing stabilized residual 
(SR). Although aerobic systems are in widespread use in the biological stage of MBT, anaerobic systems have several advantages. Firstly, the time required for anaerobic treatment is shorter. The time frame for the most commonly used process in mesophilic anaerobic chambers is no longer than 30 days, whereas aerobic treatment needs at least 3-4 months. Secondly, because the anaerobic processes are carried out in closed chambers, it is simple to manage and reduce odour emission. Thirdly, these processes can be energetically selfsustaining because the biogas that is generated can be converted into heat to maintain the desired temperature, whereas aerobic processes require more energy for aeration than they can produce [2-4]. Thus, anaerobic digestion is a more efficient treatment of the organic fraction of rMSW. However, nowadays in Poland, aerobic processes are more commonly used for stabilization and bio-drying of this organic fraction [5]. Many technical solutions with different operational parameters have been used for aerobic stabilization [6-8]. Most often, a two-stage process is used. First, the intensive thermophilic phase of aerobic stabilization takes place in bioreactors over a few weeks, during which the pathogens are removed and the organic fraction is stabilized. After this, the maturation phase takes place in aerated windrows. Sometimes, a three-stage process is used. The difference refers to the use of covered aerated windrows, preceding uncovered windrows during the maturation step. When maturation is complete, the organic fraction that was mechanically separated from rMSW is biologically stable. Typically, from 20 to $35 \%$ of water and biodegradable materials are lost, depending on the duration of treatment. To further reduce the volume of waste sent to landfill (up to $60 \%$, or even more), mechanical separation of SR should be used.

The biological stability of the organic fraction can be determined in several ways. One widely accepted method is the use of respiration indices (RI) [9-11]. For example, after a one-year observational study of the biostabilization process in a waste treatment plant, the end product was stable, as indicated by a Dynamic Respiration Index (DRI) that should be $<1000 \pm 200 \mathrm{mg} \mathrm{O}_{2} \mathrm{~kg} \mathrm{VS}^{-1} \mathrm{~h}^{-1}$ [12]. The second method of determining the biological stability of the organic fraction is oxygen consumption in loss on ignition (LOI) assays. Ball et al. [13] found that, compared to the input material $\left(330 \mathrm{~g} \mathrm{O}_{2} / \mathrm{kg} \mathrm{LOI}\right)$, oxygen consumption was reduced by $30 \%$ in immature compost $\left(230 \mathrm{~g} \mathrm{O}_{2} / \mathrm{kg}\right.$ LOI) and by $45 \%$ in mature compost (181 $\mathrm{g} \mathrm{O}_{2} / \mathrm{kg}$ LOI). Another method of assessing the effectiveness of aerobic stabilization may be comparing the composition and particle size distribution of the organic fraction $(<80 \mathrm{~mm})$ of rMSW that is input to MBT plant with those characteristics of the stabilized residual that is output. The quantity and quality of the outputs from a MBT plant vary as a function of the characteristics of the inputs. These characteristics depend on the location (urban or rural), the season, the percentage share of each type of material that is source-separated, and the methods of mechanical and biological processing employed in the plant $[14,15]$. The amount and composition of the stabilized residual, which needs to be landfilled, depend on the composition of the $<80 \mathrm{~mm}$ organic fraction that is mechanically separated from rMSW. It would be worth knowing the detailed composition of the SR, especially in the context of a circular economy. Specific circumstances of the concept of a circular economy is closely related to the $3 \mathrm{R}$ principles of the solid waste management: reduce, reuse, and recycle [16,17]. This idea includes a target for recycling of municipal solid waste (MSW) (minimum $65 \%$ of all MSW by 2030) and landfilling of solid waste (maximum $10 \%$ of all MSW by 2030) [18].

However, information is lacking on the composition of particles of different size fractions within both the $<80 \mathrm{~mm}$ organic fraction separated from rMSW and the SR. This information is needed to effectively implement pre-treatment procedures for the organic fraction and manage the material flow of residual waste. Therefore, the objective of this study was to determine the particle size distribution and composition of the $<80 \mathrm{~mm}$ fraction that is mechanically separated from rMSW as well as the stabilized residual after aerobic stabilization in each season in which waste was collected. Detailed characteristic provides a more transparent and comprehensive waste composition, enabling, to a certain extent, the directions of the management with both the $<80 \mathrm{~mm}$ fraction and the SR. 


\section{Materials and Methods}

\subsection{Technological Characteristics of the MBT Plant}

The MBT plant (north-eastern Poland) receives and processes waste from the city and 16 nearby municipalities, which have around 200,000 inhabitants. The plant has a processing capacity of $60,000 \mathrm{Mg} / \mathrm{y}$ and consists of a sorting stage, two stages of aerobic stabilization, and a landfill site. The sorting plant operates lines to separate wasted material from rMSW or from separately collected waste, such as a glass cullet cleaning line and a line for alternative fuel production (pre-RDF). After manual pre-separation of bulky waste and tearing bags, the waste is transported to the pre-sorting cabin. Then, waste is transported to a double-section drum screen (TRS Model, Sutco, Poland) with dimensions of $3 \mathrm{~m} \times 12 \mathrm{~m}$, with two mesh diameters of 80 and $300 \mathrm{~mm}$, where the waste is divided into three size fractions: $<80 \mathrm{~mm}, 80-300 \mathrm{~mm}$ and $>300 \mathrm{~mm}$. Both of the bigger fractions are directed to the sorting cabin in which secondary materials (e.g., different kinds of recyclables such as e.g., plastic made of PET, paper or cardboard) are separated. The residue after sorting of the two bigger fractions constituted pre-RDF for production of fuel from waste, or ballast that can be only landfilled. Generally, the pre-RDF mainly include combustible components, such as plastics (not including PVC), paper or cardboard being non-recyclable materials. The $<80 \mathrm{~mm}$ organic fraction is intensively aerobically stabilized in a closed reinforced concrete modules with automatic aeration and irrigation systems (4 weeks). After this, the maturation phase takes place. The material is transferred into aerated piles, covered with a membrane ( 4 weeks), and finally into uncovered piles with passive aeration (4-8 weeks). The technological parameters of the aerobic stabilization of the $<80 \mathrm{~mm}$ fraction are summarized in Table 1.

Table 1. Operating parameters of the aerobic stabilization of the $<80 \mathrm{~mm}$ fraction that was mechanically separated from rMSW.

\begin{tabular}{ccc}
\hline & Module & \\
\hline Time (weeks) & & 4 \\
Air supplied $\left(\mathrm{m}^{3} / \mathrm{h}\right)$ & 324 \\
Fan operation time (s) & 60 \\
Fan break time (s) & Covered piles & 240 \\
Time (weeks) & & 4 \\
Air supplied (m ${ }^{3} / \mathrm{h}$ ) & & $324-405$ \\
Fan operation time (s) & 80 \\
Fan break time (s) & Uncovered piles & $240-260$ \\
Time (weeks) & & 4 \\
\hline
\end{tabular}

\subsection{Analysis of Composition and Particle Size Distribution of $<80 \mathrm{~mm}$ Fraction and SR}

Samples of the $<80 \mathrm{~mm}$ fraction and SR were collected from the MBT plant in four seasons of the year i.e., summer (S), autumn (A), winter (W) and spring (Sp) in 2017-2018. After sieving of rMSW, the $<80 \mathrm{~mm}$ fraction was randomly sampled in various places to obtain a representative sample of the entire mass of this fraction (60-80 Mg/d). SR was sampled from randomly selected piles on the maturing site. Samples of the $<80 \mathrm{~mm}$ fraction and of the SR were taken in four replicates every 3-4 weeks in each season, which resulted in 32 samples in total. The weight of each sample was about $120 \mathrm{~kg}$. In the figures and in the tables the average values are shown. A cross-sectional technique was used for sample preparation. Samples were divided into 4 parts and then 2 parts were discarded. The other 2 parts constituted the sample for analysis.

The samples of the $<80 \mathrm{~mm}$ fraction and SR were separated on the sieves into the following particle size fractions: $>60 \mathrm{~mm}, 60-40 \mathrm{~mm}, 40-10 \mathrm{~mm},<10 \mathrm{~mm}$. The percent composition by particle size fractions was calculated on the basis of fresh weight. 
The size fractions, except $<10 \mathrm{~mm}$, were subjected to analysis of the composition in accordance with Polish standard (PN-Z-15006:1993P) with the introduction of these divisions: biodegradable waste (paper and cardboard, vegetable waste, other organic waste, food animal waste, and additionally textile waste), glass waste (packaging and technical glass), metal waste (ferrous, non-ferrous, and aluminium foil, and additionally mineral waste, electronic and multi-material waste), plastic waste (PET, PS, PP, HD-PE, films and others), and other waste (including polystyrene foam and diapers).

\subsection{Similarity Analyses}

To analyze the similarities between composition in particle size fractions separated from the $<80 \mathrm{~mm}$ fractions and the SR across four seasons, the Nei-Li distance [19] was calculated using the DGGEstat 1.0 program (van Hannen, the Netherlands Institute for Ecological Research, NIOO-KNAW, the Netherlands). Based on these similarities, trees were constructed (hierarchical clustering) and the distances between samples were calculated using the mean connection method (UPGMA) [20]. The validity of the resulting tree was based on four replicate samples of the composition in particle size fractions separated from the $<80 \mathrm{~mm}$ fraction and of the SR in each season. Graphical representations of the results were prepared with TreeView [21].

The following symbols were used when presenting the results of similarity analysis: $<80_{\mathrm{S}>60},<80_{\mathrm{S} 60-40},<80_{\mathrm{S} 40-10}$ - particle sizes in the $<80 \mathrm{~mm}$ fraction collected in the $\mathrm{S}$, $<80_{\mathrm{A}>60},<80_{\mathrm{A} 60-40},<80_{\mathrm{A} 40-10}$ - particle sizes in the $<80 \mathrm{~mm}$ fraction collected in the $\mathrm{A}$, $<80_{\mathrm{W}>60},<80_{\mathrm{W} 60-40},<80_{\mathrm{W} 40-10}$-particle sizes in the $<80 \mathrm{~mm}$ fraction collected in the $\mathrm{W}$, $<80_{\mathrm{Sp}>60},<80_{\mathrm{Sp} 60-40},<80_{\mathrm{Sp} 40-10}$ - particle sizes in the $<80 \mathrm{~mm}$ fraction collected in the $\mathrm{Sp}$, $\mathrm{SR}_{\mathrm{S}>60}, \mathrm{SR}_{\mathrm{S} 60-40}, \mathrm{SR}_{\mathrm{S} 40-10}$-particle sizes in the SR collected in the $\mathrm{S}$,

$\mathrm{SR}_{\mathrm{A}>60}, \mathrm{SR}_{\mathrm{A} 60-40}, \mathrm{SR}_{\mathrm{A} 40-10}$ - particle sizes in the SR collected in the $\mathrm{A}$,

$\mathrm{SR}_{\mathrm{W}>60}, \mathrm{SR}_{\mathrm{W} 60-40}, \mathrm{SR}_{\mathrm{W} 40-10}$ - particle sizes in the SR collected in the $\mathrm{W}$,

$\mathrm{SR}_{\mathrm{Sp}>60}, \mathrm{SR}_{\mathrm{Sp} 60-40}, \mathrm{SR}_{\mathrm{Sp} 40-10}$-particle sizes in the SR collected in the Sp.

\section{Results and Discussion}

3.1. Distribution of Particle Size Fractions within the $<80 \mathrm{~mm}$ Fraction and in SR in Each Season of Collection

Samples of the $<80 \mathrm{~mm}$ fraction and SR were divided into the following particle size fractions: $>60 \mathrm{~mm}, 60-40 \mathrm{~mm}, 40-10 \mathrm{~mm}$, and $<10 \mathrm{~mm}$. The proportions of these fractions depended on the season of collection. The present study showed that the proportions of the particle size fractions in $<80 \mathrm{~mm}$ fraction and in SR changed in favor of the higher content of the smaller particles in SR. Regarding the particle size fractions separated from the $<80 \mathrm{~mm}$ fraction, the $60-40 \mathrm{~mm}$ fraction constituted the largest share after collection in spring (43.6\%), and the $40-10 \mathrm{~mm}$ fraction made up the largest shares in winter and autumn ( 61.1 and $47.2 \%$, respectively). Particle size fraction $<10 \mathrm{~mm}$ constituted from 7.8 to $13 \%$ of the $<80 \mathrm{~mm}$ fraction. It should be emphasized that two bigger particle size fractions constituted from more than $40 \%$ to almost $60 \%$ of the $<80 \mathrm{~mm}$ fraction. As for the particle size fractions separated from the SR, the $<10 \mathrm{~mm}$ fraction increased and made up about $40 \%$ of SR collected in all four seasons. The $40-10 \mathrm{~mm}$ fraction constituted over $30 \%$ of SR collected in all seasons except spring; in this SR it constituted 25\%. Both of the particle size fractions dominated in SR over the particle size fractions $<40 \mathrm{~mm}$ constituting from ca. $66 \%$ to up to $80 \%$ of SR (Figure 1 ). 


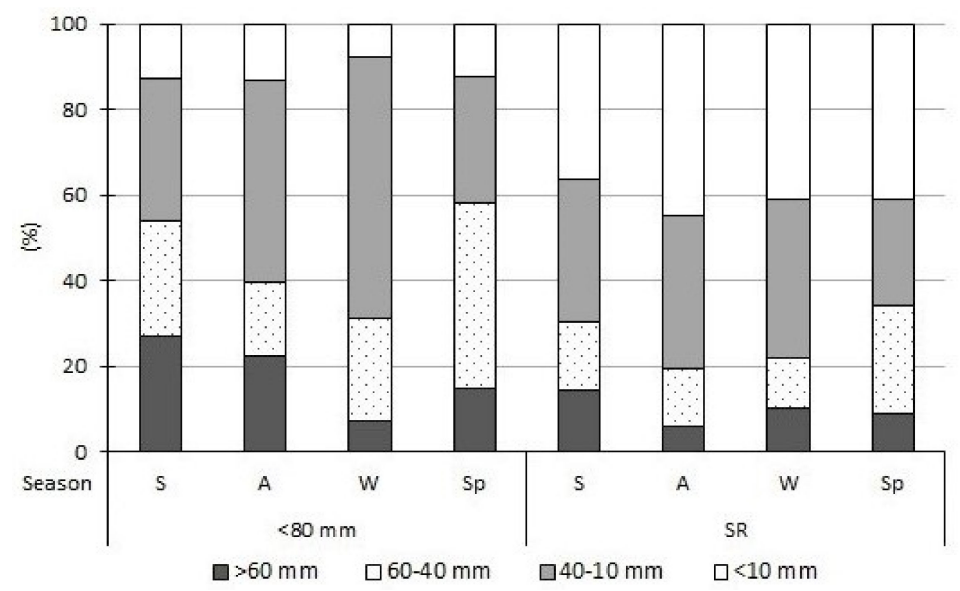

Figure 1. The percent share of particle size fractions within the $<80 \mathrm{~mm}$ fraction and in SR in each season of collection.

To the best our knowledge, there is a lack of information about the detailed composition and particle size distribution of both the $<80 \mathrm{~mm}$ fraction and also the SR from full-scale MBT plants. Only a few studies have indicated that, in the product of the aerobic stabilization of the organic fraction of rMSW, the content of the $<10 \mathrm{~mm}$ fraction is high. For example, Połomka and Jedrczak [22] found that the $<10 \mathrm{~mm}$ particle size fraction constituted 51.4-52.5\% of SR (referred to as compost-like-output in their study) after aerobic stabilization. Dias et al. [23] found an even higher content of this fraction, about $80 \%$, in the residual material after aerobic stabilization. Knowledge of the relative amounts of the particle size fractions separated from SR seems to be especially important in the context of possible utilization of the particular size fractions. Literature data on this subject are still scarce. Only a few studies have shown that the smallest particle size fraction of SR can be further processed mechanically in an external installation, then recycled and used for, e.g., road construction or concrete production. Połomka and Jedrczak [22] tested the possibility of using the $0-5 \mathrm{~mm}$ fraction of SR for winter road maintenance. Although the grain size of the SR was appropriate according to European standards, it was too light and contained too much organic matter. Thus, this research direction was abandoned. However, the authors indicated that the $5-10 \mathrm{~mm}$ particle size fraction of SR could be used successfully for preparation of concrete mix formula and met the class standards for concrete. Moreover, they also recently found that the $0-10 \mathrm{~mm}$ fraction of SR can be used for constructing road foundations [22].

\subsection{Composition and Percent Share of Biodegradable Waste in the $<80 \mathrm{~mm}$ and SR Particle Size Fractions in Each Collection Season}

Residual municipal solid waste is a very heterogenous material that can have an impact on the composition of selected or separated waste fractions. Edjabou et al. [24] found that food waste constituted $41-45 \%$ of rMSW. This food waste consisted of vegetable (31-37\%) and animal-derived food wastes (7-10\%). The authors showed that material fractions, such as paper, board, etc. constituted $26 \%$ of the rMSW. This relatively high percentage of recyclables in rMSW indicates that initiatives are required to increase the source-segregation of recyclables. Additionally, to fulfill the requirements of the Landfill Directive [25] concerning the limitation of the landfilling of biodegradable waste, many MBT plants have been established. The mechanical steps in an MBT plant allow for the separation of the over-sized fraction (typically above the $80 \mathrm{~mm}$ ) characterized by a high caloric value (about 2800-3000 kcal/ $\mathrm{kg}$ wet weight (w.w.)) and low water content (about 200-250 g/ kg w.w.). This fraction could be used for RDF production after bio-drying and mechanical rendering processes. The under-sized fraction contains even up to $80 \%$ of organic matter and has a high water content (about 600 to $700 \mathrm{~g} / \mathrm{kg}$ w.w.) [26]. Because this under-sized fraction, commonly $<80 \mathrm{~mm}$, contains a relatively high amount of biodegrad- 
able waste with a high content of organic matter, this is subjected to stabilization during which the organic matter content decreases. After stabilization, the SR should have higher biological stability and a lower content of both biodegradable waste and organic matter.

Figure 2 shows the percentage share of only biodegradable waste in particle size fractions (except $<10 \mathrm{~mm}$ ) (Figure 2a,b) and composition of biodegradable waste of the $<80 \mathrm{~mm}$ and SR depending on collection season (Figure 2c,d). It was considered that the biodegradable waste in samples from the $<80 \mathrm{~mm}$ fraction and SR included vegetable waste, other organic waste, food animal waste, paper and cardboard waste, and also textile material. The share of biodegradable waste in the $<80 \mathrm{~mm}$ fraction and SR in the three particle size fractions changed depending on the collection season. The biodegradable waste in the $<80 \mathrm{~mm}$ fraction ranged from $44.1 \%$ (A) to $54.3 \%$ (Sp), whereas in the SR fraction it ranged from $8.5 \%(\mathrm{~W})$ to $17.1 \%$ (S) (Figure $2 \mathrm{a}, \mathrm{b}$ ).
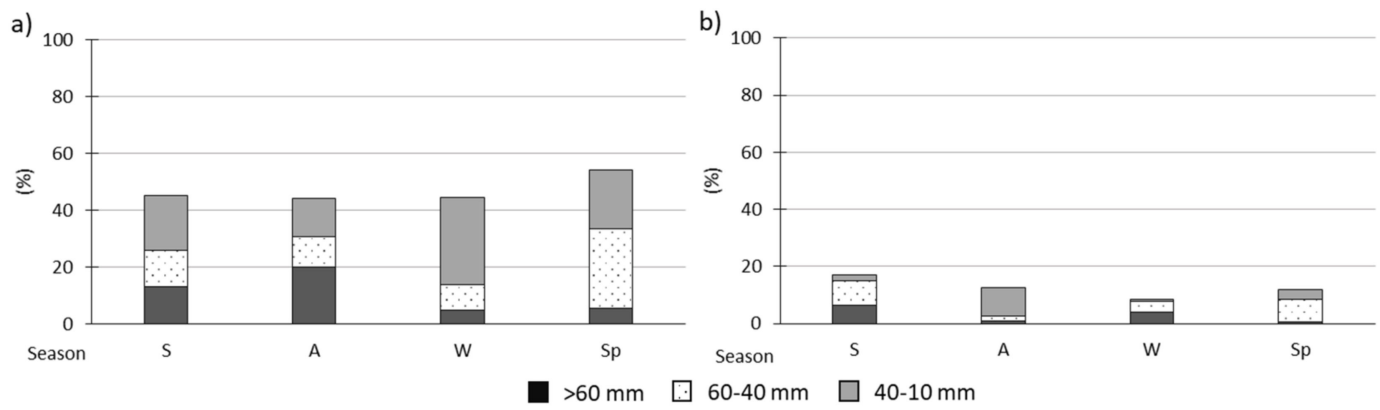

c)

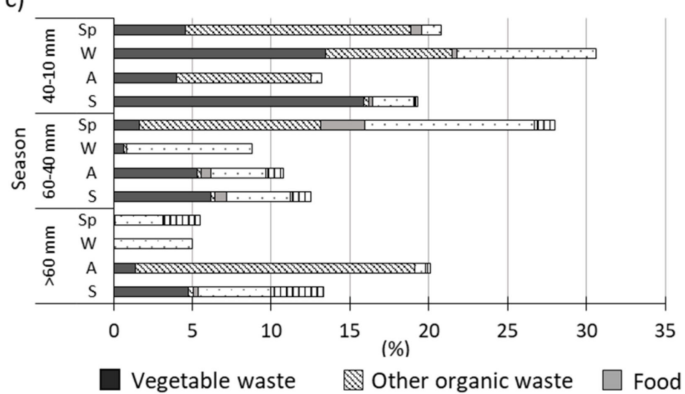

d)

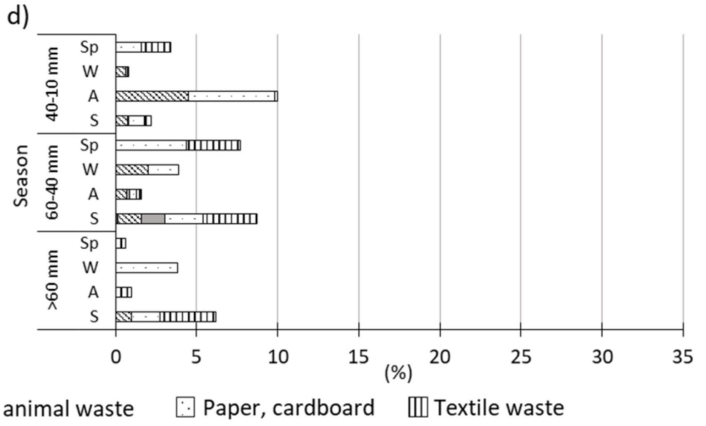

Figure 2. The percentage share of only biodegradable waste in particle sizes fractions of the $<80 \mathrm{~mm}(\mathbf{a})$ and SR (b) in each season of collection, and composition of biodegradable waste in particle sizes fractions of the $<80 \mathrm{~mm}$ fraction (c) and the SR (d) in each season of collection; particle size fractions $<10 \mathrm{~mm}$ were not taken into consideration.

It should be emphasized that it was not possible to separate the particular components of biodegradable waste in the $<10 \mathrm{~mm}$ particle size fractions of both the $<80 \mathrm{~mm}$ fraction and SR. Therefore, it was not included in the analysis. However, researchers indicated that the small size fraction of MSW contains organic matter, and if it was taken into account, the content of biodegradable waste in the $<80 \mathrm{~mm}$ fraction would be higher. For example, Bernat et al. [27] found that in a small size fraction of 0-20 mm separated from MSW with a humidity of $50 \%$, the LOI, commonly meaning the organic matter content, was $31.4 \%$ of dry matter. To compare, in the same study, the 20-80 mm size fraction of MSW was characterized; the humidity was $38 \%$, and the LOI was $61.3 \%$ TS. This means that smaller fraction was less reactive than bigger one, but the $0-20 \mathrm{~mm}$ fraction cannot be treated as a completely mineral fraction, as it previously was considered. Jędrczak et al. [28] also found that the $<10 \mathrm{~mm}$ fraction separated from MSW contained $31.7 \pm 7.5 \%$ water and showed a LOI of $29.8 \pm 7.1 \% \mathrm{DM}$, which confirmed its unstable character and indicated the relatively high amount of the organic matter was present. However, in another study, Połomka and Jẹdrczak [29] indicated that the fraction $<10 \mathrm{~mm}$ originated from the SR (about $50 \%$ of the SR) was mainly a mixture of ash and sand. This means that the $<10 \mathrm{~mm}$ fraction of SR should be less reactive and more stable than this particle size fraction from MSW. 
Although, in the present study, the composition of biodegradable waste was not determined in particle size fractions $<10 \mathrm{~mm}$, it can be considered that the percent share of biodegradable waste, especially in the $<80 \mathrm{~mm}$ fraction, would be higher than presented in Figure 2. However, later in the manuscript it was not taken into account in the calculations. In the case of the SR, this it is of minor importance because organic matter in particle sizes fractions $<10 \mathrm{~mm}$ probably was stabilized. The quality of the final product from MBT plants is regulated [30]. The most commonly used biological stability indicators of the SR are the concentration of total organic carbon (TOC) in the eluate $(<250 \mathrm{mg}$ TOC $/ \mathrm{L})$, the content of TOC $(\leq 18 \%)$, and the calorific value of the SR $(\leq 6000 \mathrm{~kJ} / \mathrm{kg} \mathrm{DM})$ [31]. Another reference method can be the AT4 test. The EU local standards determine the required AT4 value in the final product, e.g., in Germany, it should be $5 \mathrm{mg} \mathrm{O}_{2} / \mathrm{g} \mathrm{DM}$, whereas in Austria the value can be a little higher $\left(7 \mathrm{mg} \mathrm{O} / 2 / g\right.$ DM). In Poland it should not exceed $10 \mathrm{mg} \mathrm{O}_{2} / \mathrm{g}$ DM. At the end of the first stage of two-stage aerobic stabilization of the organic fraction of MSW with the use of closed reactors and a composted aerated pile, the stabilized material should have an AT4 value of $20 \mathrm{mg} \mathrm{O}_{2} / \mathrm{g}$ DM [32].

Regarding the particle size fractions, for example, in the $>60 \mathrm{~mm}$ fraction separated from the $<80 \mathrm{~mm}$ fraction, the share of biodegradable waste was highest in autumn and lowest in winter (20\% and 5.0\%, respectively) (Figure 2a,b). In the 60-40 mm fraction, in contrast, the share of biodegradable waste was highest in spring $(28.0 \%)$ and lowest in winter $(8.8 \%)$.

After 8 weeks of aerobic stabilization of $<80 \mathrm{~mm}$ fraction, the share of biodegradable waste in the particle size fractions decreased, especially in the $>60 \mathrm{~mm}$ fraction of SR. For example, in SR collected in spring, biodegradable waste constituted $0.6 \%$ of the total mass of SR. Aerobic stabilization decreased the share of biodegradable waste in the $>60 \mathrm{~mm}$ fraction of SR collected in autumn by 95\%, and substantially reduced the share of biodegradable waste in this fraction of SR that was collected in the spring.

Połomka and Jedrczak [29] indicated that the reduction of the total mass of waste processed at a full-scale MBT installation should be in the range of 25 to $45 \%$. Additionally, the overall efficiency of organic matter reduction in the underscreen fraction $(0-80 \mathrm{~mm})$ during stabilization was in the range of 40 to $60 \%$. In the case of the present study, the efficiency of biodegradable waste reduction ranged from $60 \%$ to even $80 \%$. However, if we took into account the smallest fraction $(<10 \mathrm{~mm})$, the efficiency would be lower.

Regarding the composition of biodegradable waste in the $<80 \mathrm{~mm}$ fraction (Figure 2c), in the particle size fraction $>60 \mathrm{~mm}$ vegetable waste and paper, cardboard dominated (each constituted ca. $4.6 \%$ ) in summer. In autumn, other organic waste constituted up to $17 \%$. Paper and cardboard (5\%) were only separated in winter. In particle size fraction 40-60 mm vegetable wastes dominated in summer and autumn (each constituted ca. $5 \%$ ). The highest share in spring had other organic waste and paper, cardboard (both ca. 22\%). In winter, paper, cardboard dominated (ca. 8\%).

Regarding the composition of biodegradable waste in SR (Figure 2d), in the particle size fraction $>60 \mathrm{~mm}$ vegetable waste content decreased in summer to $1 \%$, and paper and cardboard to $1.8 \%$. The highest share was textile waste ca. 3.5\%. In autumn, paper and cardboard and textile waste were separated $(0.3$ and $0.6 \%)$. In winter paper, cardboard content decreased to $3.8 \%$. In spring only textile waste $(0.6 \%)$ was found. In particle size fraction $60-40 \mathrm{~mm}$, vegetable waste was separated only in summer $(0.15 \%)$. In this season, textile waste $(3.3 \%)$ dominated. The content of the other organic waste (ca. $0.7 \%)$ was highest in autumn. In winter other organic waste and paper, cardboard (ca. 1.9\%) were separated. Paper and cardboard and textile waste constituted ca. 4.4 and ca. 3.3\%. In particle size fraction $40-10 \mathrm{~mm}$ paper and cardboard dominated in summer and autumn (ca. $1 \%$ and ca. $5.3 \%$ ), while food animal waste content were lowest $(0.02 \%$ and $0.03 \%$ ). Other organic waste (ca. $0.6 \%$ ) dominated in winter. In spring paper, cardboard and textile waste (ca. $1.7 \%$ ) were separated. 
3.3. Contaminants, Their Composition and the Contamination Ratio (CR) in the $<80 \mathrm{~mm}$ Fraction and SR in Each Season

A detailed analysis of the composition of particle size fractions separated from the $<80 \mathrm{~mm}$ fraction and SR showed their heterogeneous characteristics (Tables 2 and 3).

The biodegradable waste contained contaminants, e.g., metal, glass, plastic, stones, bricks etc. Figure 3 showed the share of biodegradable waste and the four main contaminants in particle size fractions separated from the $<80 \mathrm{~mm}$ fraction and SR depending on the season, assuming that particular particle size fraction was $100 \%$. As it was mentioned biodegradable waste in $<80 \mathrm{~mm}$ fraction constituted up to $55 \%$, whereas this waste in the SR was from 2.6 to 5.3 times lower. This means that contaminants in the $<80 \mathrm{~mm}$ constituted ca. half amount of the whole fraction. During aerobic stabilization, the reduction of the organic matter and water content took place. Due to this process, the mass of stabilized materials decreased. However, the content of materials that were considered as contaminants, e.g., metal, glass, plastic, increased in relation to the whole mass. Thus, due to stabilization and reduction of the organic matter in the SR, the contaminants compacted and their share increased to $83-91 \%$ of the total mass of the sample.
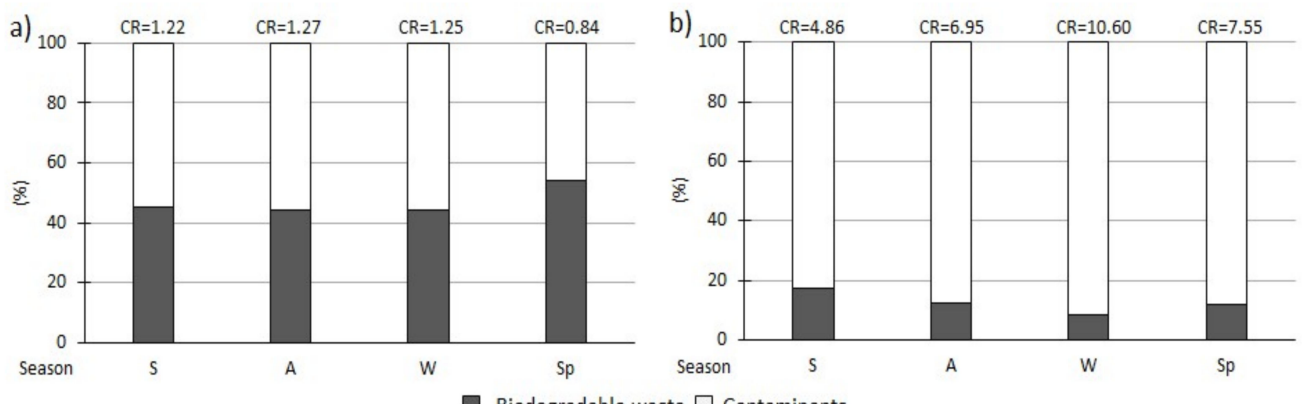

c)

d)
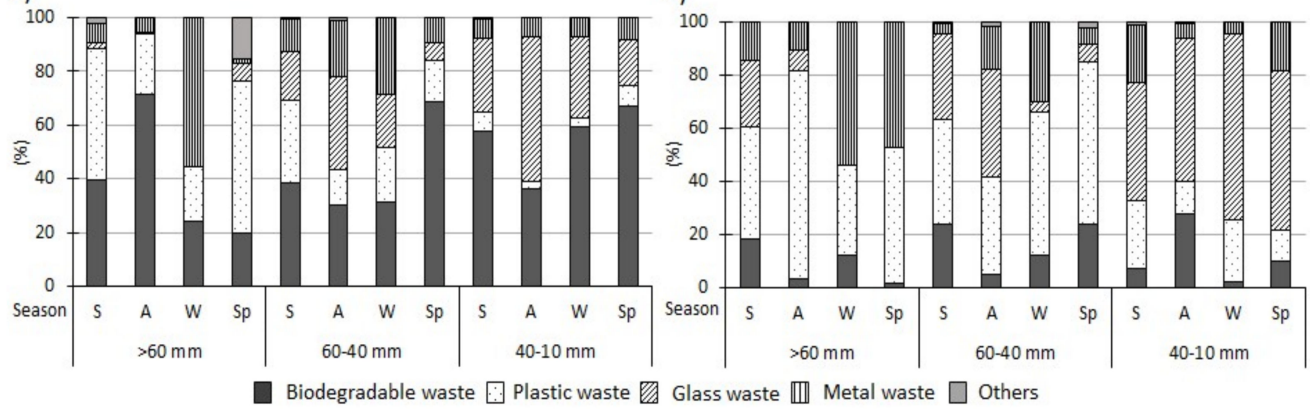

Figure 3. The share of biodegradable waste and contaminants in the $<80 \mathrm{~mm}$ fraction (a) and SR (b) in each season of collection, the share of biodegradable waste and four main groups of contaminants in particle size fractions separated from the $<80 \mathrm{~mm}$ fraction (c) and SR (d) in each season of collection.

The share of contaminants in the SR is on over $50 \%$ and depends on its particle size distribution [4]. The authors found that the final product of aerobic stabilization of the organic fraction mechanically selected from rMSW showed presence of improper materials, mainly paper, plastic and glass. Dias et al. $[33,34]$ characterized residual material after aerobic stabilization from 5 different MBT plants, and found that glass and stones predominated, constituting 32-67\% and 10-26\%, respectively. Some identified materials, such as plastic, metal, ceramic and brick, were present in small percentages, constituting from 2 to $13 \%$ of the residual material. The share of the materials that were difficult to identify was $12-49 \%$. The authors considered it to be mainly organic matter, but it is debatable whether it is appropriate to treat the smallest fraction of residual material as organic matter, especially when it is present in such large amounts. 
Table 2. Composition of the particle size fractions in the $<80 \mathrm{~mm}$ fraction separated from rMSW in each season of collection.

\begin{tabular}{|c|c|c|c|c|c|c|c|c|c|c|c|c|}
\hline \multirow{2}{*}{ Composition (\%) } & \multicolumn{3}{|c|}{$\mathrm{S}$} & \multicolumn{3}{|c|}{$\mathbf{A}$} & \multicolumn{3}{|c|}{$\mathbf{W}$} & \multicolumn{3}{|c|}{$S p$} \\
\hline & $>60 \mathrm{~mm}$ & $60-40 \mathrm{~mm}$ & $40-10 \mathrm{~mm}$ & $>60 \mathrm{~mm}$ & $60-40 \mathrm{~mm}$ & $40-10 \mathrm{~mm}$ & $>60 \mathrm{~mm}$ & $60-40 \mathrm{~mm}$ & $40-10 \mathrm{~mm}$ & $>60 \mathrm{~mm}$ & $60-40 \mathrm{~mm}$ & $40-10 \mathrm{~mm}$ \\
\hline \multicolumn{13}{|c|}{ Biodegradable waste } \\
\hline Vegetable waste & 4.72 & 6.15 & 15.88 & 1.39 & 5.31 & 4.00 & 0 & 0.67 & 13.45 & 0.11 & 1.66 & 4.54 \\
\hline Other organic waste & 0.32 & 0.27 & 0.28 & 17.71 & 0.23 & 8.50 & 0 & 0.16 & 8.02 & 0 & 11.49 & 14.32 \\
\hline Food animal waste & 0.31 & 0.73 & 0.29 & 0 & 0.63 & 0.04 & 0 & 0 & 0.30 & 0 & 2.79 & 0.66 \\
\hline Paper, cardboard & 4.64 & 4.06 & 2.61 & 0.69 & 3.51 & 0.66 & 5.00 & 7.98 & 8.83 & 3.02 & 10.79 & 1.28 \\
\hline Textile waste & 3.31 & 1.29 & 0.24 & 0.31 & 1.12 & 0 & 0 & 0 & 0 & 2.37 & 1.28 & 0 \\
\hline Sum & 13.30 & 12.50 & 19.30 & 20.10 & 10.80 & 13.20 & 5.00 & 8.80 & 30.60 & 5.50 & 28.00 & 20.80 \\
\hline \multicolumn{13}{|c|}{ Plastic waste } \\
\hline PET & 0.65 & 0.30 & 0 & 0 & 0 & 0.07 & 0 & 0 & 0 & 3.80 & 0.48 & 0 \\
\hline PS & 0.94 & 0.64 & 0 & 0.44 & 2.47 & 0 & 0 & 1.08 & 0 & 1.60 & 0 & 0 \\
\hline PP & 0.52 & 0 & 0 & 0.47 & 0 & 0 & 0 & 0 & 0 & 0 & 0 & 0 \\
\hline HD-PE & 1.63 & 1.39 & 0.08 & 0.17 & 0.27 & 0 & 0 & 0 & 0.38 & 0 & 0.08 & 0 \\
\hline Films & 10.41 & 5.88 & 1.11 & 4.58 & 1.95 & 0.48 & 0 & 4.36 & 0.43 & 10.50 & 3.09 & 0.92 \\
\hline Other & 2.45 & 1.85 & 1.15 & 0.63 & 0.01 & 0.43 & 4.11 & 0.19 & 0.76 & 0 & 2.75 & 1.41 \\
\hline Sum & 16.60 & 10.06 & 2.35 & 6.30 & 4.70 & 0.99 & 4.11 & 5.62 & 1.57 & 15.90 & 6.40 & 2.33 \\
\hline \multicolumn{13}{|c|}{ Glass waste } \\
\hline Packaging & 0.18 & 5.67 & 9.31 & 0.10 & 6.84 & 17.33 & 0 & 5.53 & 15.59 & 1.87 & 2.64 & 5.38 \\
\hline Sum & 0.85 & 5.88 & 9.31 & 0.10 & 12.33 & 19.47 & 0 & 5.53 & 15.59 & 1.87 & 2.64 & 5.38 \\
\hline \multicolumn{13}{|c|}{ Metal waste } \\
\hline Ferrous metals & 0.58 & 0.15 & 0 & 0 & 0 & 0.27 & 0 & 0 & 0.05 & 0 & 1.38 & 0.67 \\
\hline Non-ferrous metals & 0.50 & 1.10 & 0.01 & 0 & 0 & 0 & 0 & 0 & 0.03 & 0 & 0.41 & 0 \\
\hline Aluminum foil & 0 & 0.19 & 0.21 & 0 & 0 & 0.09 & 0 & 0 & 0.38 & 0 & 0 & 0 \\
\hline Mineral waste & 0 & 1.96 & 1.60 & 1.35 & 4.18 & 1.65 & 3.98 & 7.52 & 3.22 & 0 & 0.78 & 1.87 \\
\hline Electronic waste & 0.31 & 0 & 0.51 & 0.13 & 2.04 & 0.27 & 0 & 0 & 0 & 0.50 & 0.66 & 0 \\
\hline Multi-material waste & 1.03 & 0.57 & 0 & 0.14 & 1.15 & 0.34 & 7.48 & 0.51 & 0 & 0 & 0.63 & 0 \\
\hline Sum & 2.43 & 3.97 & 2.33 & 1.63 & 7.36 & 2.62 & 11.47 & 8.03 & 3.68 & 0.50 & 3.86 & 2.54 \\
\hline \multicolumn{13}{|c|}{ Others } \\
\hline Styrofoam & 0 & 0 & 0.11 & 0 & 0.05 & 0.01 & 0 & 0 & 0 & 0 & 0 & 0 \\
\hline Diapers & 0.66 & 0.23 & 0.12 & 0 & 0.33 & 0 & 0 & 0 & 0 & 4.28 & 0 & 0 \\
\hline Sum & 0.66 & 0.23 & 0.23 & 0 & 0.38 & 0.01 & 0 & 0 & 0 & 4.28 & 0 & 0 \\
\hline Total & 33.84 & 32.64 & 33.52 & 28.13 & 35.57 & 36.30 & 20.57 & 27.99 & 51.44 & 28.04 & 40.91 & 31.05 \\
\hline
\end{tabular}


Table 3. Composition of the particle size fractions in the SR depending on the season of the collection.

\begin{tabular}{|c|c|c|c|c|c|c|c|c|c|c|c|c|}
\hline \multirow{2}{*}{ Composition (\%) } & \multicolumn{3}{|c|}{$\mathrm{S}$} & \multicolumn{3}{|c|}{$\mathbf{A}$} & \multicolumn{3}{|c|}{$\mathbf{W}$} & \multicolumn{3}{|c|}{$\mathrm{Sp}$} \\
\hline & $>60 \mathrm{~mm}$ & $60-40 \mathrm{~mm}$ & $40-10 \mathrm{~mm}$ & $>60 \mathrm{~mm}$ & $60-40 \mathrm{~mm}$ & $40-10 \mathrm{~mm}$ & $>60 \mathrm{~mm}$ & $60-40 \mathrm{~mm}$ & $40-10 \mathrm{~mm}$ & $>60 \mathrm{~mm}$ & $60-40 \mathrm{~mm}$ & $40-10 \mathrm{~mm}$ \\
\hline \multicolumn{13}{|c|}{ Biodegradable waste } \\
\hline Vegetable waste & 0.05 & 0.16 & 0 & 0 & 0 & 0 & 0 & 0 & 0 & 0 & 0 & 0 \\
\hline Other organic waste & 0.95 & 1.42 & 0.76 & 0 & 0.67 & 4.46 & 0 & 1.99 & 0.60 & 0 & 0 & 0 \\
\hline Food animal waste & 0 & 1.44 & 0.02 & 0 & 0.21 & 0.03 & 0 & 0 & 0.13 & 0 & 0 & 0 \\
\hline Paper, cardboard & 1.75 & 2.38 & 0.96 & 0.34 & 0.39 & 5.32 & 3.80 & 1.91 & 0.08 & 0 & 4.36 & 1.58 \\
\hline Textile waste & 3.45 & 3.30 & 0.43 & 0.64 & 0.32 & 0.19 & 0 & 0 & 0 & 0.60 & 3.34 & 1.82 \\
\hline Sum & 6.20 & 8.70 & 2.17 & 0.98 & 1.60 & 10.00 & 3.80 & 3.90 & 0.80 & 0.60 & 7.70 & 3.40 \\
\hline PET & 0.35 & 0 & 0.03 & 1.30 & 0 & 0.25 & 0 & 0 & 1.17 & 3.14 & 1.14 & 0 \\
\hline PS & 0 & 0 & 0 & 0 & 2.16 & 0 & 0 & 0 & 0 & 0 & 0 & 0 \\
\hline PP & 0 & 0 & 0 & 0 & 0 & 0 & 0 & 0 & 0 & 0 & 0 & 0 \\
\hline HD-PE & 0 & 4.41 & 0 & 0 & 1.37 & 1.43 & 0 & 0 & 0.61 & 0 & 0 & 0.94 \\
\hline Films & 8.11 & 8.79 & 3.76 & 22.97 & 5.84 & 0.81 & 10 & 10.75 & 5.11 & 14.14 & 18.33 & 0.12 \\
\hline Other & 5.67 & 1.35 & 3.88 & 0 & 2.81 & 1.88 & 0 & 6.41 & 1.50 & 0 & 0.28 & 2.57 \\
\hline Sum & 14.12 & 14.54 & 7.66 & 24.27 & 12.18 & 4.38 & 10.18 & 17.15 & 8.39 & 17.28 & 19.75 & 4.03 \\
\hline \multicolumn{13}{|c|}{ Glass waste } \\
\hline Packaging & 8.19 & 7.01 & 9.87 & 2.38 & 13.44 & 18.79 & 0 & 1.27 & 24.82 & 0 & 2.15 & 18.75 \\
\hline Sum & 8.19 & 11.94 & 13.15 & 2.38 & 13.44 & 19.46 & 0 & 1.27 & 25.51 & 0 & 2.15 & 20.33 \\
\hline \multicolumn{13}{|c|}{ Metal waste } \\
\hline Ferrous metals & 0.17 & 0 & 0 & 1.68 & 0.16 & 0.14 & 0 & 3.00 & 0.56 & 0 & 0 & 1.35 \\
\hline Non-ferrous metals & 0 & 0.47 & 3.28 & 0 & 0 & 0 & 6.00 & 0 & 0 & 0 & 0 & 0.14 \\
\hline Aluminum foil & 0 & 0.71 & 1.66 & 0 & 0.91 & 0.09 & 0 & 0 & 0.12 & 0 & 0 & 0.12 \\
\hline Mineral waste & 4.48 & 0 & 1.64 & 0 & 4.13 & 1.33 & 10.41 & 6.15 & 0.73 & 15.88 & 2.08 & 2.90 \\
\hline Electronic waste & 0 & 0 & 0.02 & 0.21 & 0 & 0.48 & 0 & 0 & 0 & 0 & 0 & 0 \\
\hline Multi-material waste & 0.21 & 0.29 & 0 & 1.35 & 0.27 & 0 & 0 & 0 & 0 & 0 & 0 & 2.00 \\
\hline Sum & 4.86 & 1.47 & 6.59 & 3.23 & 5.48 & 2.03 & 16.49 & 9.48 & 1.61 & 15.88 & 2.08 & 6.17 \\
\hline \multicolumn{13}{|c|}{ Others } \\
\hline Styrofoam & 0 & 0 & 0.25 & 0 & 0.06 & 0.01 & 0 & 0 & 1.43 & 0 & 0.63 & 0 \\
\hline Diapers & 0 & 0.15 & 0 & 0 & 0.38 & 0.11 & 0 & 0 & 0 & 0 & 0 & 0 \\
\hline Sum & 0 & 0 & 0 & 0 & 0.44 & 0.13 & 0 & 0 & 1.43 & 0 & 0.63 & 0 \\
\hline Total & 33.37 & 36.81 & 29.82 & 30.86 & 33.15 & 35.99 & 30.47 & 31.80 & 37.73 & 33.76 & 32.31 & 33.93 \\
\hline
\end{tabular}


The smallest fraction of residual material should be stabilized, and thus should be considered mainly a mineral fraction. The origin of all of the contaminants in the material after stabilization is because the stabilized feedstocks is commonly the organic fraction mechanically separated from mixed MSW. Montejo et al. [4] found that this kind of feedstock contained about $64.13 \pm 9.83 \%$ of biodegradable matter originating mainly from food waste. Cesaro et al. [35] showed that biodegradable material (67\% of the total weight) represented the main component of the organic fraction separated from MSW. They also determined great amount of contaminants such as plastics (19\%), paper (8\%), inerts (5\%), and metals (1\%). A higher content of biodegradable material than in the present study may result from the fact that the authors did not separate the particle size fraction $<10 \mathrm{~mm}$, and probably considered all this tiny material as the organic matter.

In the present study, the contamination ratio (CR) was determined as the ratio of the percentage share of the contaminants to that of the biodegradable waste. The lower value of CR, the composition of $<80 \mathrm{~mm}$ fraction is more suitable for stabilization because it contains more biodegradable waste. The CR depended on the season of collection. In the $<80 \mathrm{~mm}$ fraction CR ranged from 0.84 (spring) to ca. 1.2 in the rest of the year. The ratio of contamination in SR increased, the lowest was in summer (4.86); the higher (10.6) in winter.

In particle size fraction $>60 \mathrm{~mm}$ of the $<80 \mathrm{~mm}$ fraction, plastic waste constituted 49 and $57 \%$, respectively in summer and spring. In this particle size fraction in winter metal waste (ca. 56\%) dominated as contaminants. In the particle size fractions $60-40 \mathrm{~mm}$ and 40-10 mm glass waste was separated; this contaminant in autumn accounted for about 35\% and $54 \%$.

In particle size fractions in the SR after 8 weeks of aerobic stabilization, the shares of plastic waste constituted up to $79 \%$ (A). As for the $>60 \mathrm{~mm}$ particle size fraction, metal waste made up 54 and $47 \%$, respectively in $\mathrm{W}$ and $\mathrm{Sp}$. The share of glass waste in particle size fraction $40-10 \mathrm{~mm}$ (from $44 \%$ in summer to $70 \%$ in winter) was higher than that in other two particle size fraction (Figure 3).

Figure 4 presents the composition of the four main groups of contaminants, in particle size fractions separated from the $<80 \mathrm{~mm}$ fraction and SR depending on the season. The content of a particular contaminant was assumed to be $100 \%$.

In the $<80 \mathrm{~mm}$ fraction, irrespective of the season and particle size fraction, except $>60 \mathrm{~mm}$ (winter), films constituted considerable share in plastic waste, ranged from $27 \%$ to $77 \%$. The second dominant group was other plastic materials. In particle size fraction $>60 \mathrm{~mm}$ (winter), the whole amount of plastic waste made up others plastic materials. A similar tendency was observed in the SR, in which these two groups of plastic waste dominated.

The three common groups of waste, i.e., ferrous, non-ferrous, and aluminium foil, were the components of metal waste. In the $<80 \mathrm{~mm}$ fraction, these groups dominated in particle size fraction $>60 \mathrm{~mm}$ in summer (ca. $40 \%$ ), and these groups were found in particle size fraction $40-10 \mathrm{~mm}$ and $60-40 \mathrm{~mm}$ in spring, in which they constituted $45 \%$ and $26 \%$, respectively. Additionally, mineral waste, electronic and multi-material waste were included in contaminant as metal waste. In both particle size fractions, 40-10 mm and $60-40 \mathrm{~mm}$, mineral waste made up from $63 \%$ (autumn) to $93 \%$ (winter). Mineral waste constituted almost $83 \%$ of the particle size fraction $>60 \mathrm{~mm}$ in autumn.

The SR characterized higher diversity of the components of metal waste, however, for example, in particle size fractions $>60 \mathrm{~mm}$ (in summer and spring) and 60-40 $\mathrm{mm}$ (in spring) mineral waste accounted for almost $100 \%$ of metal waste.

The packaging glass dominated both in particle size fractions separated from the $<80 \mathrm{~mm}$ fraction and SR. Most of glass waste was found in particle size fraction 40-10 mm, in both the $<80 \mathrm{~mm}$ fraction and SR (Figure 4 ). 
a)

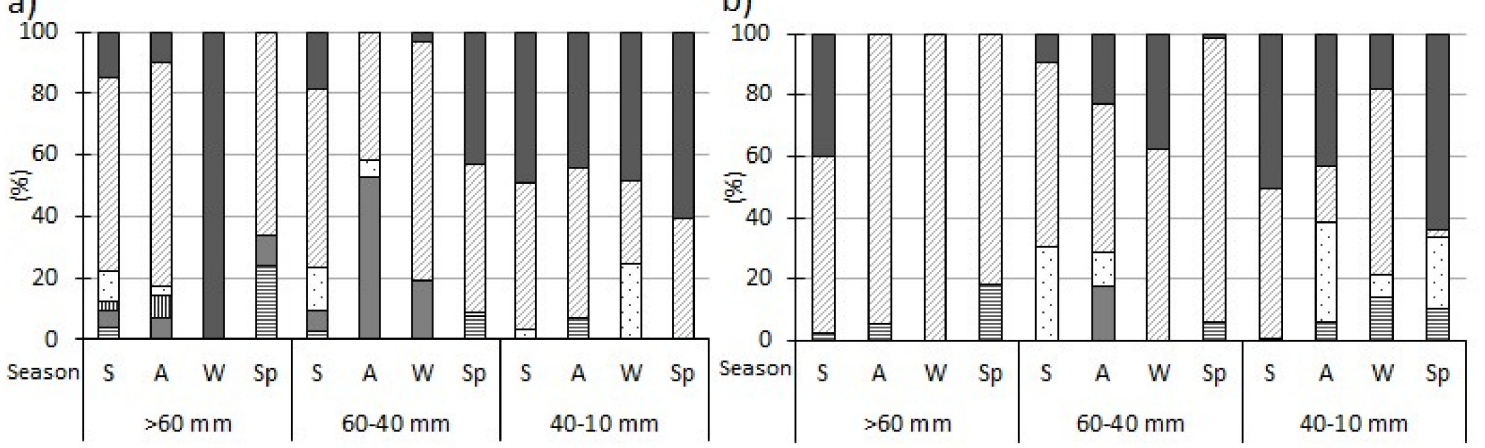

目PET $\square$ PS $\square$ HD-PE $\square$ Films $\square$ Other

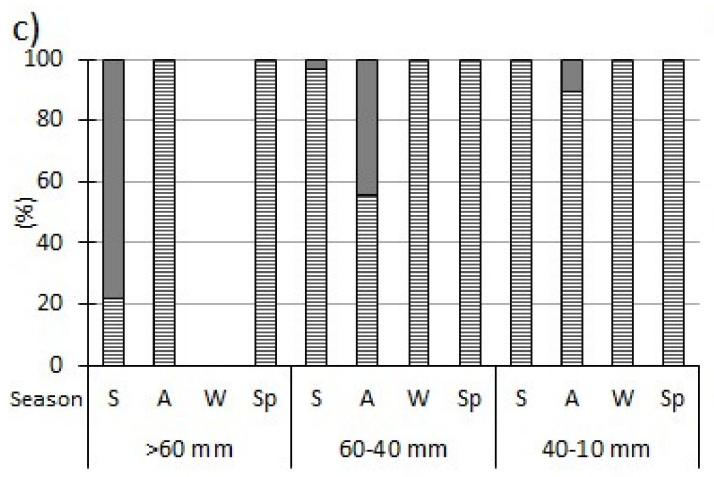

d)

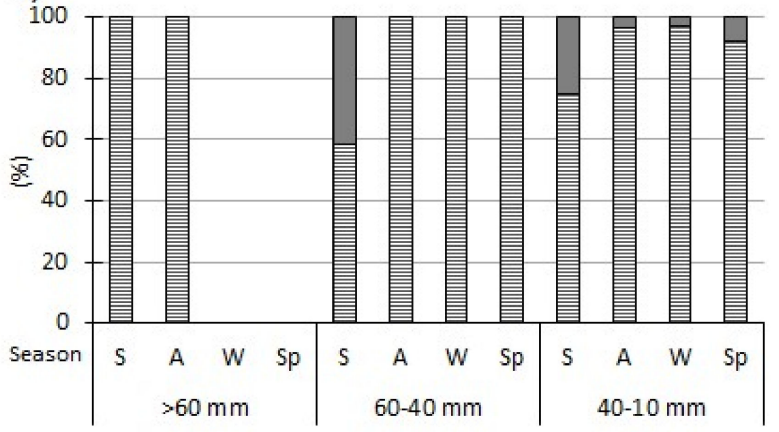

目 Packaging $\square$ Technical

e)

f)

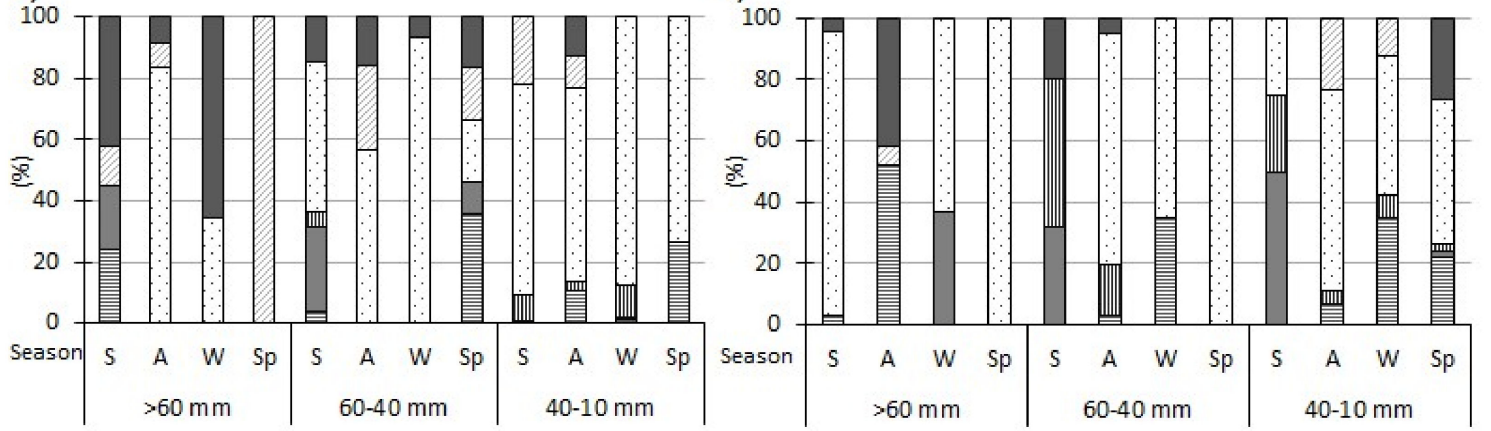

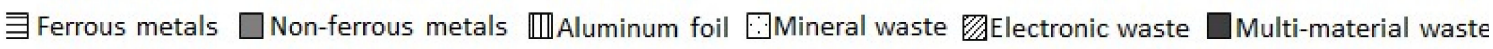

g)

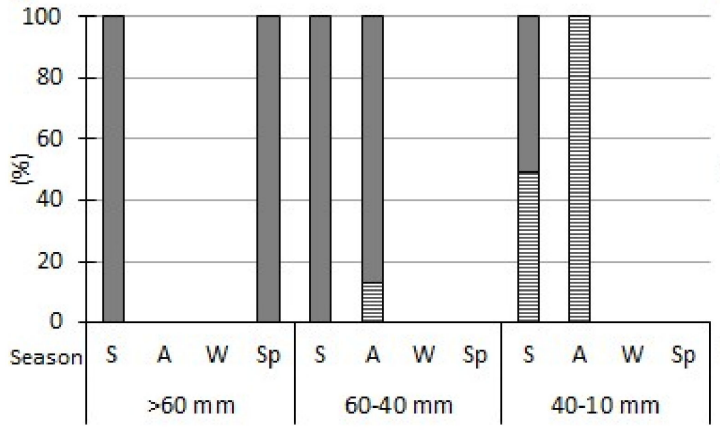

h)

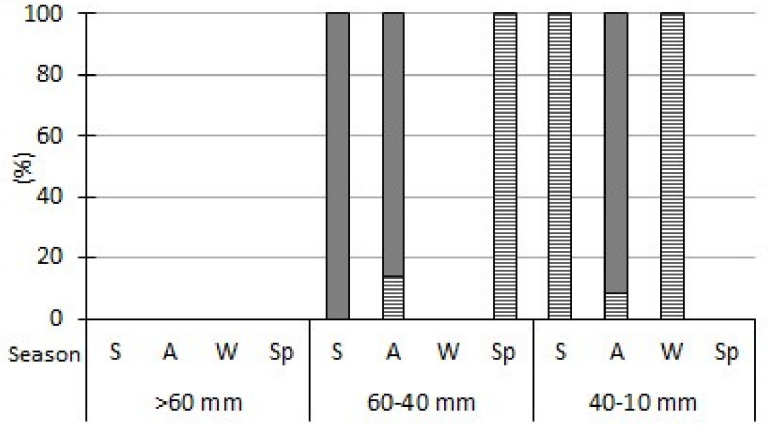

目Styrofoam $\square$ Diapers

Figure 4. Composition of the four main groups of contaminants in particle size fractions separated from the $<80 \mathrm{~mm}$ fraction $(\mathbf{a}, \mathbf{c}, \mathbf{e}, \mathbf{g})$ and SR $(\mathbf{b}, \mathbf{d}, \mathbf{f}, \mathbf{h})$ in each season of collection; plastic waste $(\mathbf{a}, \mathbf{b})$, glass waste $(\mathbf{c}, \mathbf{d})$, metal waste $(\mathbf{e}, \mathbf{f})$, other waste (g,h). 
3.4. Similarities in the Composition of Particle Size Fractions Separated from the $<80 \mathrm{~mm}$ Fraction and $S R$

Hierarchical clustering based on Nei-Li distances was used to examine the similarities of the composition in particle size fractions separated from the $<80 \mathrm{~mm}$ fraction and SR (Figure 5). In the case of both the $<80 \mathrm{~mm}$ fraction and SR, two main clusters were distinguished.
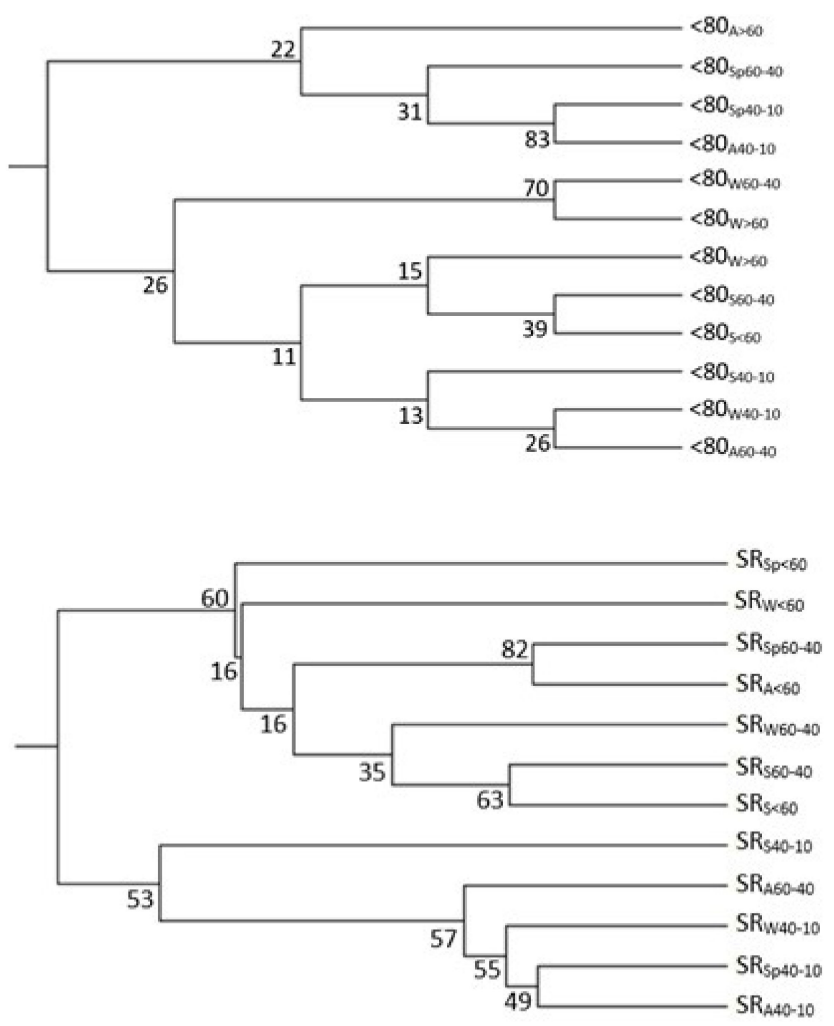

Figure 5. Clustering of particle size fractions based on the composition of the $<80 \mathrm{~mm}$ fraction (a) and SR (b) in four seasons.

Regarding the $<80 \mathrm{~mm}$ fraction, the first cluster, grouped with a similarity of $22 \%$, included particle size fractions $>60 \mathrm{~mm}$ and $40-10 \mathrm{~mm}$ separated in autumn, and $60-40 \mathrm{~mm}$ and 40-10 mm separated in spring. The second of these two clusters was further divided into two groups: the first, with $70 \%$ similarity, included particle size fractions $>60 \mathrm{~mm}$ and 60-40 mm separated in the winter; the second, with 11\% similarity, included particle size fractions $>60 \mathrm{~mm}$ and $60-40 \mathrm{~mm}$, respectively separated in spring and autumn; and particle size fraction $40-10 \mathrm{~mm}$ separated in winter, as well as all particle size fractions collected in summer (Figure 5a). Relatively low similarity and gathering the one cluster various particle size fractions indicated a high heterogenicity of the composition of the $<80 \mathrm{~mm}$ fraction.

In the same manner, the similarities of the particle size fractions of SR were examined using hierarchical clustering (Figure 5b). It should be emphasized that the similarities of the particle size fractions of SR were higher than the $<80 \mathrm{~mm}$ fraction. The first cluster, grouped with a similarity of $60 \%$, the particle size fractions $>60 \mathrm{~mm}$ in all seasons and particle size fractions 60-40 mm separated in spring, summer and winter, except autumn. The second cluster, grouped with a similarity of $53 \%$, and included the lowest particle size fraction $40-10 \mathrm{~mm}$ and this $60-40 \mathrm{~mm}$ separated in autumn. Hierarchical clustering indicates that aerobic stabilization increases the similarity of the composition of the particle size fractions. In practice, this means that, separation of the SR on the particle size fractions could be an effective solution when selecting the size fraction with the higher content of the desired component, for example glass, metal or plastic. After separation, a compaction of the components takes place in a particular size fraction. Because, to the authors' knowledge, 
this is the first time such a statistical analysis was used to examine the similarities in the composition of particle size fractions separated from the $<80 \mathrm{~mm}$ fraction and SR, comparison of the present results with those of other studies cannot be performed.

\subsection{Potential Utilisation of the $S R$}

Although recently MBT plants are commonly used systems in waste management in many countries, the studies on the composition of SR are not numerous, thus the comparison of the results of the present study with others is limited. The interest in the possibility of recovering SR from MBT plant is increasing [36], especially considering the large amounts that are being produced in efforts to divert waste from landfills [37-39]. One of the possible ways to recover SR is as landfill cover material for promoting vegetation growth [40]. Application to degraded and/or contaminated soils of the SR has been also proposed [37]. The results of the present study indicated that without additional treatment of the SR this is impossible to promote using as a fertilizer. The $<80 \mathrm{~mm}$ organic fraction obtained by size separation, which, due to non-source separation and poor selectivity, contains a high amount of the contaminants. The composition indicates that fertilizer potential of the SR is limited by the method to separate the organic fraction from rMSW and also by methods to remove improper materials from the organic fraction. However, there are few studies that have shown new directions in SR utilization. For example, preliminary studies by Dias et al. $[33,34]$ showed that it is necessary to make an effort to develop and improve glass recovery from the residual material from the biological stage of MBT plants. The share of glass compacted in this material can be as large as $75-85 \%$. Those authors tested simple, small-scale equipment that ensured an effectiveness of glass recovery of $82-91 \%$. Nevertheless, the final concentrate still contained a considerable percentage of contaminants, and it could not be forwarded to the glass recycling industry, which requires at least $98 \%$ of glass content. A further study by Połomka et al. [41] aimed to assess the technical feasibility of recovering the mineral fractions from the SR on a technological line designed for glass recovery. The amount of glass in the SR ranged from ca. $11.4 \%$ to ca. $17.3 \%$. After biostabilization, the SR was separated into three fractions: 0-10 mm, 10-35 mm and 35-80 mm. The $10-35 \mathrm{~mm}$ fraction constituted $33.6-39.5 \%$ of the mass of the SR and contained $31-41 \%$ glass. This fraction was directed to the production of glass concentrate. After glass recovery, the glass content was $92.8-99.5 \%$ of sample weight. This product was accepted by glass recycling plants due to its low level of contaminants and appropriate particle size.

\section{Conclusions}

The present study found that, in the SR after aerobic stabilization of the $<80 \mathrm{~mm}$ fraction of rMSW, the smaller particle size fractions (up to $40 \mathrm{~mm}$ ) predominate. In these size fractions, the main contaminants are plastic, glass, metal, and other waste, with plastic waste constituting up to $79 \%$ of the SR. In the $>60 \mathrm{~mm}$ fraction, metal waste made up $47 \%$ to $54 \%$, and in the $40-10 \mathrm{~mm}$ fraction, glass amounted to $44 \%$ to $70 \%$. This knowledge about the seasonal variation in the characteristics of the $<80 \mathrm{~mm}$ fraction will help to provide ideas for the collection, transportation and treatment of heterogenous rMSW generated in different seasons. Additionally, the information provided in this paper can provide directions for future studies and be incorporated in databases on the composition of the $<80 \mathrm{~mm}$ fraction and SR, which are important for designing systems for recovering and disposing of municipal solid waste. Finally, the results of this study confirm that a potential weakness of mechanical separation in MBT plants is that many contaminants in the $<80 \mathrm{~mm}$ fraction remain in the final product of stabilization. However, the high content of glass and metal in the SR after aerobic stabilization of the $<80 \mathrm{~mm}$ fraction of rMSW suggests that the SR could become a source of secondary materials that could be profitably recovered before landfilling. 
Author Contributions: Conceptualization, K.B., I.W.-B.; methodology, M.Z., I.S.; formal analysis, K.B., I.W.-B.; investigation, M.Z., I.S.; data curation, K.B., I.W.-B.; writing-original draft preparation, K.B., I.W.-B.; writing-review and editing, K.B., I.W.-B., M.Z.; visualization, K.B., M.Z.; supervision, I.W.-B.; project administration, K.B.; funding acquisition, K.B. All authors have read and agreed to the published version of the manuscript.

Funding: This study is part of the research project funded by the National Science Centre, Poland (Grant No. 2016/21/B/NZ9/03625).

Institutional Review Board Statement: Not Applicable.

Informed Consent Statement: Not Applicable.

Data Availability Statement: Not Applicable.

Acknowledgments: The authors are grateful to Hab. Eng. Agnieszka Cydzik-Kwiatkowska for her support in conducting the similarity analyses.

Conflicts of Interest: The authors declare no conflict of interests.

\section{References}

1. Montejo, C.; Tonini, D.; Márquez, M.C.; Astrup, T.F. Mechanical-biological treatment: Performance and potentials. An LCA of 8 MBT plants including waste characterization. J. Environ. Manag. 2013, 128, 661-673. [CrossRef] [PubMed]

2. Soyez, K.; Plickert, S. Mechanical-biological pre-treatment of waste: State of the art and potentials of biotechnology. Acta Biotechnol. 2002, 22, 271-284. [CrossRef]

3. Fricke, K.; Santen, H.; Wallmann, R. Comparison of selected aerobic and anaerobic procedures for MSW treatment. Waste Manag. 2005, 25, 799-810. [CrossRef] [PubMed]

4. Montejo, C.; Ramos, P.; Costa, C.; Márquez, M.C. Analysis of the presence of improper materials in the composting process performed in ten MBT plants. Bioresour. Technol. 2010, 101, 8267-8272. [CrossRef]

5. Berthe, C.; Redon, E.; Feuillade, G. Fractionation of the organic matter contained in leachate resulting from two modes of landfilling: An indicator of waste degradation. J. Hazard. Mater. 2008, 154, 262-271. [CrossRef]

6. Lim, L.Y.; Bong, C.P.C.; Lee, C.T.; Klemes, J.J.; Sarmidi, M.R.; Lim, J.S. Review on the current composting practices and the potential of improvement using two-stage composting. Chem. Eng. Trans. 2017, 61, 1051-1056.

7. Onwosi, C.O.; Igbokwe, V.C.; Odimba, J.N.; Eke, I.E.; Nwankwoala, M.O.; Iroh, I.N.; Lewis Ezeogu, L.I. Composting technology in waste stabilization: On the methods, challenges and future prospects. J. Environ. Manag. 2017, 190, 140-157. [CrossRef]

8. Colon, J.; Martinez-Blanco, J.; Gabarrell, X.; Artola, A.; Sanchez, A.; Rieradevall, J.; Font, X. Environmental assessment of home composting. Resour. Conserv. Recycl. 2010, 54, 893-904. [CrossRef]

9. Adani, F.; Ubbiali, C.; Generini, P. The determination of biological stability of composts using the Dynamic Respiration Index: The results of experience after two years. Waste Manag. 2006, 26, 41-48. [CrossRef]

10. Gómez, R.B.; Lima, F.V.; Ferrer, A.S. The use of respiration indices in the composting process: A review. Waste Manag. Res. 2006, 24, 37-47. [CrossRef]

11. Ponsá, S.; Gea, T.; Sánchez, A. Different indices to express biodegradability in organic solid wastes. J. Environ. Qual. 2010, 39, 706-712. [CrossRef]

12. Adani, F.; Tambone, F.; Gotti, A. Biostabilization of municipal solid waste. Waste Manag. 2004, 24, 775-783. [CrossRef]

13. Ball, A.S.; Shahsavari, E.; Aburto-Medina, A.; Kadali, K.K.; Shaiban, A.A.; Stewart, R.J. Biostabilization of municipal solid waste fractions from an Advanced Waste Treatment plant. J. King Saud Univ. Sci. 2017, 29, 145-150. [CrossRef]

14. Robinson, H.D.; Knox, K.; Bone, B.D.; Picken, A. Leachate quality from landfilled MBT waste. Waste Manag. 2005, 25, 383-391. [CrossRef]

15. Rotter, V.S.; Kost, T.; Winkler, J.; Bilitewski, B. Material flow analysis of RDF-production processes. Waste Manag. 2004, 24, 1005-1021. [CrossRef]

16. Ghisellini, P.; Cialani, C.; Ulgiati, S. A review on circular economy: The expected transition to a balanced interplay of environmental and economic systems. J. Clean. Prod. 2016, 114, 11-32. [CrossRef]

17. Lieder, M.; Rashid, A. Towards circular economy implementation: A comprehensive review in context of manufacturing industry. J. Clean. Prod. 2016, 115, 36-51. [CrossRef]

18. EC (European Commission). Closing the Loop-An EU Action Plan for the Circular Economy. Communication from the Commission to the European Parliament, the Council, the European Economic and Social Committee and the Committee of the Regions; European Commission: Brussels, Belgium, 2015.

19. Nei, M.; Li, W.H. Mathematical model for studying genetic variation in terms of restriction endonucleases. Proc. Natl. Acad. Sci. USA 1979, 76, 5269-5273. [CrossRef]

20. Sokal, R.R.; Michener, C.D. A statistical method for evaluating systematic relationships. Univ. Kansas, Sci. Bull. 1958, 38, 1409-1438. 
21. Page, R.D.M. TreeView: An application to display phylogenetic trees on personal computers. Bioinformatics 1996, 12, 357-358. [CrossRef]

22. Połomka, J.; Jędrczak, A. Potential of mineral fraction in compost-like-output, methods of its obtaining and the possibility of using it in the context of circular economy. Materials 2020, 13, 3023. [CrossRef] [PubMed]

23. Dias, N.; Carvalho, M.T.; Pina, P. Characterization of Mechanical Biological Treatment reject aiming at packaging glass recovery for recycling. Miner. Eng. 2012, 29, 72-76. [CrossRef]

24. Edjabou, E.M.; Jensen, M.B.; Götze, R.; Pivnenko, K.; Petersen, C.; Scheutz, C.; Astrup, T.F. Municipal solid waste composition: Sampling methodology, statistical analyses, and case study evaluation. Waste Manag. 2015, 36, 12-23. [CrossRef]

25. Council Directive 1999/31/EC of 26 April 1999 on the landfill of waste. Off. J. Eur. Community 1999, 182, 1-19.

26. Adani, F.; Scatigna, L.; Genevini, P. Biostabilization of mechanically separated municipal solid waste fraction. Waste Manag. Res. 2000, 18, 471-477. [CrossRef]

27. Bernat, K.; Zielińska, M.; Cydzik-Kwiatkowska, A.; Wojnowska-Baryła, I. Biogas production from different size fractions separated from solid waste and the accompanying changes in the community structure of methanogenic Archaea. Biochem. Eng. J. 2015, 100, 30-40. [CrossRef]

28. Jedrczak, A.; Myszograj, S.; Połomka, J. The composition and properties of Polish waste focused on biostabilisation in MBT plants during the heating season. Energies 2020, 13, 1072. [CrossRef]

29. Połomka, J.; Jedrczak, A. Efficiency of waste processing in the MBT system. Waste Manag. 2019, 96, 9-14. [CrossRef]

30. Cesaro, A.; Belgiorno, V.; Guida, M. Compost from organic solid waste: Quality assessment and European regulations for its sustainable use. Resour. Conserv. Recycl. 2015, 94, 72-79. [CrossRef]

31. Bayard, R.; de Araújo Morais, J.; Ducom, G.; Achour, F.; Rouez, M.; Gourdon, R. Assessment of the effectiveness of an industrial unit of mechanical-biological treatment of municipal solid waste. J. Hazard. Mater. 2010, 175, 23-32. [CrossRef]

32. Sidełko, R.; Siebielska, I.; Janowska, B.; Skubała, A. Assessment of biological stability of organic waste processed under aerobic conditions. J. Clean. Prod. 2017, 164, 1563-1570. [CrossRef]

33. Dias, N.; Belo, N.; Máximo, A.; Carvalho, M.T. Recovery of glass contained in the heavy residual fraction of Portuguese mechanical Biological Treatment Plants. J. Clean. Prod. 2014, 79, 271-275. [CrossRef]

34. Dias, N.; Máximo, A.; Belo, N.; Carvalho, M.T. Packaging glass contained in the heavy residual fraction refused by Portuguese Mechanical and Biological Treatment plants. Resour. Conserv. Recycl. 2014, 85, 98-105. [CrossRef]

35. Cesaro, A.; Russo, L.; Farina, A.; Belgiorno, V. Organic fraction of municipal solid waste from mechanical selection: Biological stabilization and recovery options. Environ. Sci. Pollut. Res. 2016, 23, 1565-1575. [CrossRef]

36. MacLeod, I.; Savage, A.L.; Pahl, O.; Baird, J. Decline in microbial activity does not necessarily indicate an end to biodegradation in MSW-biowaste: A case study. Bioresour. Technol. 2008, 99, 8626-8630. [CrossRef]

37. Farrell, M.; Jones, D.L. Use of composts in the remediation of heavy metal contaminated soil. J. Hazard. Mater. 2010, 175, 575-582. [CrossRef]

38. Pantini, S.; Verginelli, I.; Lombardi, F. Analysis and modeling of metals release from MBT wastes through batch and up-flow column tests. Waste Manag. 2015, 38, 22-32. [CrossRef]

39. Pantini, S.; Verginelli, I.; Lombardi, F.; Scheutz, C.; Kjeldsen, P. Assessment of biogas production from MBT waste under different operating conditions. Waste Manag. 2015, 43, 37-49. [CrossRef]

40. Angermeier, R.; Tintner, J.; Smidt, E.; Ottner, R.; Matiasch, L.; Binner, E.; Böhm, K. Development of mechanically biologically treated municipal solid waste under different vegetation types. J. Environ. Eng. 2011, 137, 340-346. [CrossRef]

41. Połomka, J.; Jędrczak, A.; Myszograj, S. Recovery of stabilizer glass in innovative MBT Installation-An analasys of new technological procedure. Materials 2020, 13, 1356. [CrossRef] 